Dedicated to Prof. Billy E. Rhoades on the occasion of his $90^{\text {th }}$ anniversary

\title{
On Caristi's fixed point theorem in metric spaces with a graph
}

\section{NANTAPORN CHUENSUPANTHARAT and DHANANJAY GOPAL}

\begin{abstract}
.
We generalize the Caristi's fixed point theorem for single valued as well as multivalued mappings defined on a metric space endowed with a graph and $w$-distance. Particularly, we modify the concept of the (OSC)-property due to Alfuraidan and Khamsi (Alfuraidan M. R. and Khamsi, M. A., Caristi fixed point theorem in metric spaces with graph, Abstr. Appl. Anal., (2014) Art. ID 303484, 5.) which enable us to reformulated their stated graph theory version theorem (Theorem 3.2 in Alfuraidan M. R. and Khamsi, M. A., Caristi fixed point theorem in metric spaces with graph, Abstr. Appl. Anal., (2014) Art. ID 303484, 5. ) to the case of $w$-distance. Consequently, we extend and improve some recent works concerning extension of Banach Contraction Theorem to $w$-distance with graph e.g. (Jachymski, J., The contraction principle for mappings on a metric space with graph, Proc. Amer. Math. Soc., 136 (2008), No. 4, 1359-1373; Nieto, J. J., Pouso, R. L. and Rodriguez-Lopez R., Fixed point theorems in ordered abstract spaces, Proc. Amer. Math. Soc., 135 (2007), 2505-2517 and Petrusel, A. and Rus, I., Fixed point theorems in ordered L-spaces endowed with graph, Proc. Amer, Math. Soc., 134 (2006), 411-418).
\end{abstract}

Acknowledgments. The authors are thankful to the learned referees for their deep observations and pertinent suggestions, which greatly helped us to improve the paper significantly. The authors also thank to Professor Mohamed Amine Khamsi for his helpful advice over the topic of this paper during his visit at KMUTT, therefore gratefully acknowledge to Professor Poom Kumam for all supports. This project was supported by Bansomdejchaopraya Rajabhat University.

\section{REFERENCES}

[1] Abdou, A. A. N., Khamsi, M. A., Fixed points of multivalued contraction mappings in modular metric spaces, Fixed Point Theory Appl., (2014), 2014:249, 10 pp.

[2] Alfuraidan, M. R., Jorquera, E. D. and Khamsi, M. A., Fixed point theorems for monotone Caristi inward mappings, Numer. Funct. Anal. Optim., 39 (2018), No. 10 , 1092-1101

[3] Alfuraidan, M. R. and Khamsi, M. A., Caristi fixed point theorem in metric spaces with graph, Abstr. Appl. Anal., (2014), Art. ID 303484, 5

[4] Aleomraninejad, S. M. A, Rezapour, Sh. and Shahzad, N., Fixed point results on subgraphs of directed graphs, Math. Sci. (Springer), 7 (2013), Art. 41, 3 pp.

[5] Banach, S., Sur les opérations dans les ensembles abstraits et leur application aux équations intégrales, Fund. Math., 3 (1922), 133-181

[6] Brondsted, A., Fixed point and partial orders, Proc. Amer. Math. Soc., 60 (1976), 365-366

[7] Browder, F. E., On a theorem of Cristi and Kirk, in: Proc. Seminar on Fixed Point Theory and Its Application, Dalhouse University, June 1975, Academic Press. 1975, pp. 23-27

Received: 30.01.2020; In revised form: 09.06.2020; Accepted: 10.06.2020

2010 Mathematics Subject Classification. 47H10, 47H09.

Key words and phrases. Caristi's fixed point, w-distance, (OSC)-property.

Corresponding author: Nantaporn Chuensupantharat; nantaporn.chuen@gmail.com 
[8] Caristi, J., Fixed point theorem for mappings satisfying inwardness conditions, Trans. Amer. Math. Soc., 215 (1976), 241-251

[9] Downing, D., Kirk, W. A., A generalization of Caristi's theorem with application to nonlinear mapping theory, Pacific J. Math., 69 (1977), 339-345

[10] Ekeland I., Sur les problems variationnels, Comptes Rendus Acad. Sci., Paris, 275 (1972), 1057-1059

[11] Ganga, B. T. and Lakshmikantham, V., Fixed point theorems in partially ordered metric spaces and applications, Nonlinear Anal., 65 (2006), No. 7, 1379-1393

[12] Hassen, A. and Dong, Z., Refinements of Caristi's fixed point theorem, J. Nonlinear Sci. Appl., 9 (2016), No. 6, 4084-4097

[13] Jachymski, J. R., Caristi's fixed point theorem and selection of set-valued contractions, J. Math. Appl., 227 (1998), 55-67

[14] Jachymski, J. R., Converse to fixed point theorems of Zermelo and Caristi, Nonlinear Anal., 52 (2003) $1455-1463$

[15] Jachymski, J., The contraction principle for mappings on a metric space with graph, Proc. Amer. Math. Soc., 136 (2008), No. 4, 1359-1373

[16] Kada, O., Suzuki, T. and Takahashi, W., Nonconvex minimization theorems and fixed point theorems in complete metric spaces, Math. Japon., 44 (1996), No. 2, 381-391

[17] Khamsi, M. A. and Kirk, W. A., An introduction to metric spaces and fixed point theory, Pure and Applied Mathematics Wiley-Interscience, New York, (2001)

[18] Khamsi, M. A., Remarks on Caristi's fixed point theorem, Nonlinear Anal., 71 (2009), 227-231

[19] Kirk, W. A. and Caristi, J., Mapping theorems in metric and Banach spaces, Bull. L'Acad. Polon. Sci., 25 (1975), 891-894

[20] Kirk, W. A. and Shahzad, N., Generalized metrics and Caristi's theorem, Fixed Point Theory Appl. 2013, 2013:129, 9 pp.

[21] Karim, C., Abderrahim, E., Kabi, M. and Samih, L., of Kirk-Saliga fixed point theorem in a metric space with a reflexive digraph, Int. J. Math. Math. Sci., (2018) Art. ID 1471256, 6 pp.

[22] Nieto, J. J. and Rodriguez-Lopez, R., Contractive mapping theorems in partially ordered sets and application to ordinary differential equations, (2005), 223-239

[23] Nieto, J. J., Pouso R. L. and Rodriguez-Lopez, R., Fixed point theorems in ordered abstract spaces, Proc. Amer. Math. Soc., 135 (2007), 2505-2517

[24] Petrusel, A. and Rus I., Fixed point theorems in ordered L-spaces endowed with graph, Proc. Amer, Math. Soc., 134 (2006), 411-418

[25] Ran, A. C. M. and Reurings, M. C. B., A fixed point theorem in partially ordered sets and some applications to matrix equations, Proc. Amer. Math. Soc., 132 (2004), 1435-1443

[26] Sridarat, P. and Suantai S., Caristi fixed point theorem in metric spaces with a graph and its applications, J. Nonlinear, Conv. Annal., 7 (2016) 1417-1428

[27] Sullivan, F., A characterization of complete metric spaces, Proc. Amer, Math. Soc., 85 (1981) 345-346

[28] Suzuki, T., Caristi's fixed point theorem in semimetric spaces, Journal of Fixed Point Theory and Applications (2018) doi.org/10.1007/s11784-018-0492-y

[29] Takahashi, W., Existence theorems generalizing fixed point theorems for multivalued mappings, Fixed point theory and applications (M. A. Thera and J.B. Baillon Eds.), Pitman Research Notes in Mathematics Series 252,397-406, John Wiley Sons, New York, (1991). MR92m:54078

[30] Turinici, M., Maximal elements in a class of order complete metric spaces, Math. Japonica, 25 (1980), No. 5, 511-517

[31] Xian, Z., Fixed point theorems of multivalued monotone mappings in ordered metric spaces, Appl. Math. Lett., 23 (2010), No. 3, 235-240

DEPARTMENT OF MATHEMATICS AND STATISTICS

FACULTY OF SCIENCE AND TECHNOLOGY

BANSOMDEJCHAOPRAYA RAJABHAT UNIVERSITY, 1061 ISARAPHAB 15 RD., 10600, THAILAND

Emailaddress: nantaporn.chuen@gmail.com, gopaldhananjay@yahoo.in; dg@amhd.svnit.ac.in 